\title{
THE PRINCIPAL'S INSTRUCTIONAL LEADERSHIP ABILITY IN STRENGTHENING THE CHARACTER OF JUNIOR HIGH SCHOOL STUDENTS OF MUHAMMADIYAH
}

\author{
Akif Khilmiyah $^{1}$, Giri Wiyono ${ }^{2}$, Fitriah M. Suud ${ }^{3 *}$ \\ ${ }^{1,3}$ Universitas Muhammadiyah Yogyakarta, Indonesia; ${ }^{2}$ Universitas Negeri Yogyakarta, Indonesia. \\ Email: ${ }^{1}$ akif.khilmiyah@umy.ac.id, ${ }^{2}$ giriwiyono@ uny.ac.id, ${ }^{3 *}$ fitriahmsuud@ gmail.com
}

Article History: Received on $03^{\text {rd }}$ April 2020, Revised on $30^{\text {th }}$ April 2020, Published on $18^{\text {th }}$ May 2020

\begin{abstract}
Purpose of the study: This study aims to determine the ability of the principal in carrying out Instructional Leadership to improve teachers' teaching performance so that it has an impact on improving the character of students.

Methodology: The type of this research is evaluative descriptive. The subjects selected by purposive sampling and triadic included 15 principals, 150 teachers, and 450 students in Yogyakarta. The data collection techniques using observation, interviews, questionnaires, and documentation. The data analysis techniques using mixed methods. The quantitative data were analyzed using descriptive statistics and linear regression. In contrast, the qualitative data were analyzed using Miler and Huberman's theory, which included four stages: reduction, display, triangulation, and conclusion.
\end{abstract}

Main Findings: First, mild juvenile delinquency is still practiced by students. Secondly, character strengthening is done through an extracurricular program, orderly book socialization, cooperation with external parties. Third, the instructional leadership ability of principals is still low. Fourth, the magnitude of the influence of Instructional Leadership in changing students' characters obtained a percentage of $12 \%$, while other factors influence $78 \%$; and the inhibiting factor for instructional leadership of school principals is the lack of collaboration between schools and parents.

Applications of this study: The results of this study can provide significant benefits in the discipline of character education and educational psychology. The school leaders can use the findings in this study to tackle juvenile delinquency in junior high school.

Novelty/Originality of this study: It turns out that to reduce and eliminate juvenile delinquency is not enough just with Instructional Leadership. The most significant factor that can help minimize adolescent familiarization is the existence of good cooperation between parents and teachers or the school.

Keywords: Instructional Leadership, Principal, Strengthening of Character, Juvenile Delinquency, Junior High School.

\section{INTRODUCTION}

Education experts have long recognized the importance of the role of Instructional Leadership (Daniëls, 2019; Orven 2019) (learning leadership) in improving teacher professionalism. The Principal's Instructional Leadership Ability is an essential factor in school organizations, especially concerning his responsibilities in improving the quality of learning in schools (Gorton, 1991; Hallinger\&Leithwood, 1994). The critical role of Instructional Leadership in fostering professionalism of teachers should have implications in improving the character of students. Because improvements in learning in the classroom will be able to change the knowledge and behavior of students for the better. Therefore, the Principal's leadership needs to divert attention from merely conducting organizational coaching to the teacher (Suud, 2018), to professional coaching by focusing on improving the performance of learning in schools. The improvement of learning in this school must be directed towards efforts to improve achievement and improve student character.

Principals as leaders of learning in schools (Chris, 2020) must be robust and courageous in setting high expectations (high expectations) on the quality of teacher performance and improvement in achievement and development of student character. Among the characteristics of the Principal who has the ability to learn is to have the ability to understand well the teaching program, often visible in the classroom observing the teaching teacher, as well as providing feedback to the teacher in fixing learning problems in class and problems experienced by students (Davis and Thomas, 1989; De Roche, 1985; Gorton and Schneider, 1991). The results of the study indicate that the role of learning leadership influences the growth of learning achievement and the improvement of student character. It can be seen through increasing teacher satisfaction in carrying out their professional roles (Smith and Andrew, 1989). In other studies, it was also found that through the improvement of the school's cultural climate and improvements in learning practices, teachers could improve the personality traits of students (Heck, Larsen, and Marcoulides, 1990; Ubben and Hughes, 1992).

Effective principals' leadership (Jean, 2020) largely determines the school's success. According to Lipham's(2003) study of productive and successful schools, it is almost always determined by the principal's leadership abilities. One of the elements forming school excellence is primarily determined by the success of the principal in applying values, norms, spirituality, and ethics as the basis of character education (Arifin, 2017; Mulyadi, 2010). Therefore as an effort to realize the Muhammadiyah school that can form students with noble, intelligent, and competitive character, principals are needed who have Instructional Leadership (learning leadership) capabilities, as the main conditions determining the 
success of school governance efforts, school accountability (Noelle, 2020), and public imaging of school excellence. The success of school principals in improving the quality of education in schools is inseparable from the mastery of their competencies and abilities in playing their duties, roles, and functions as headmaster.

As stated in Permendiknas No.13 of 2007 concerning the Principal's standard that "Principals are expected to have personal, managerial, entrepreneurial, supervisory, and social competence." But in reality, not all school principals have a good mastery of competencies. As the results of the preliminary research conducted by researchers to 30 principals at the junior level, the observations made by researchers, especially many principals of junior high schools, have not mastered all competencies in their entirety. There is a tendency for junior high school principals to only master many competencies. As the results of a survey conducted in 2007 by the Directorate of Education Personnel showed that the competence of principals was still weak. Personality competence (67.3\%), managerial (47.1\%), entrepreneurship $(55.3 \%)$, supervision $(40.41 \%)$, and social $(64.2 \%)$. The results of mapping the competency of principals nationally conducted by LPPKS and LPMP throughout Indonesia in 2010 showed data that was not much different. The average mastery of all sub-competencies from the five national competency dimensions is $76 \%$. Principal competency test results in 2015 , of 856 principals from all regions of Indonesia only found $16 \%$ of principals who carry out the leadership role of learning, the rest mostly performed other roles, either as school managers or dealing with administrative problems and educational infrastructure (Bafadal, 2016).

Likewise, the results of research (khilmiyah, 2017) to 119 prospective Muhammadiyah principals who took part in training from LP2KS was that the lowest leadership competency of Muhammadiyah principals of instructional leadership. The data is reinforced by the evidence of the still rampant gang and brawl among Muhammadiyah Middle School students in the Yogyakarta municipality, which occurred later, as quoted in the Facebook account Info CegatanJogja in June-August 2017. It proves that the leadership ability of instructional leadership Muhammadiyah Junior High School is still not optimal. Seeing this event, various questions and assumptions arose from the stakeholders of the Muhammadiyahschool regarding the cause of reducing the character of Muhammadiyah school students.

Effective principals' leadership determines the success of schools. According to Lipham's research (2003), productive or successful schools are almost always determined by the principal's leadership. One of the strengths of a school is mostly determined by the success of the principal in applying values, norms, spirituality, and ethics as the basis of character education (Arifin, 2010b; Mulyadi, 2010). Therefore, this research becomes essential and very strategic to do to improve the instructional leadership abilities of the Muhammadiyah headmaster (Baidarus, Hamami, Suud, \&Rahmatullah, 2020). This research is also to prevent the misbehavior of Muhammadiyah Middle School students' misbehavior that deviates from the provisions of Islamic moral character.

\title{
METHODOLOGY
}

This research model adopts the R\&D development model of Plomp (1997: 5) using five phases, namely (1) preliminary investigation phase, (2) design phase, (3) construction phase, (4) revision phase, and (5) implementation phase. This model was chosen because it is relevant to the purpose of the study and achieves each stage. In the pre-development period (Research) activities include the investigation phase. This first-year research uses the preliminary investigation phase. The subjects of this study are triadically, namely 15 school principals, 150 teachers, and 450 students throughout DIY. Subjects were selected by purposive sampling based on consideration of the number of cases of student delinquency that occurred and differences in school culture in character education. Data collection techniques through observation, interviews, questionnaires, and documentation. Data analysis techniques were carried out by mixed methods. For quantitative data analyzed with descriptive statistics and linear regression. While qualitative data were analyzed using Miler and Huberman's theory with four stages, namely reduction, display, triangulation, and provisional conclusions.

\section{RESULTS AND DISCUSSION}

\section{Forms of Negative Behavior of Muhammadiyah Middle School Students}

Based on the results of interviews with 15 principals of Muhammadiyah Junior High School in Yogyakarta, data obtained, that the form of harmful behavior acts of Muhammadiyah Junior High School students is in the form of moral violations, as expressed by the principals as follows:

\begin{abstract}
"Most behavioral violations in students of Muhammadiyah Depok, Imogiri, and Pleret Junior High School are committing moral violations, such as smoking, scribbling, tardiness, ditching school, bullying friends, joining gangs for brawls, hanging out after lessons, long hair, using motorbikes without owning a SIM, and are lazy to pray."
\end{abstract}

The data above shows that the form of the negative behavior of Muhammadiyah Middle School students, known by teachers and principals, is the real behavior of students in schools. All of these negative behaviors are still in the category of mild delinquency. Their misbehavior is still related to low motivation to learn (such as ditching, being late for class, hanging out), self-expression (such as doodles, long hair, wearing a motorcycle), and desires to be recognized by the group (such as joining a gang, fighting among students, bullying friends). All of the delinquency's sources are because they are lazy to pray, which should be explored further by the principal and teachers, to be repaired earlier. 
It can be seen that: Bad habits by Muhammadiyah Middle School students can be seen from the results of students' selfreports in Figure 1:

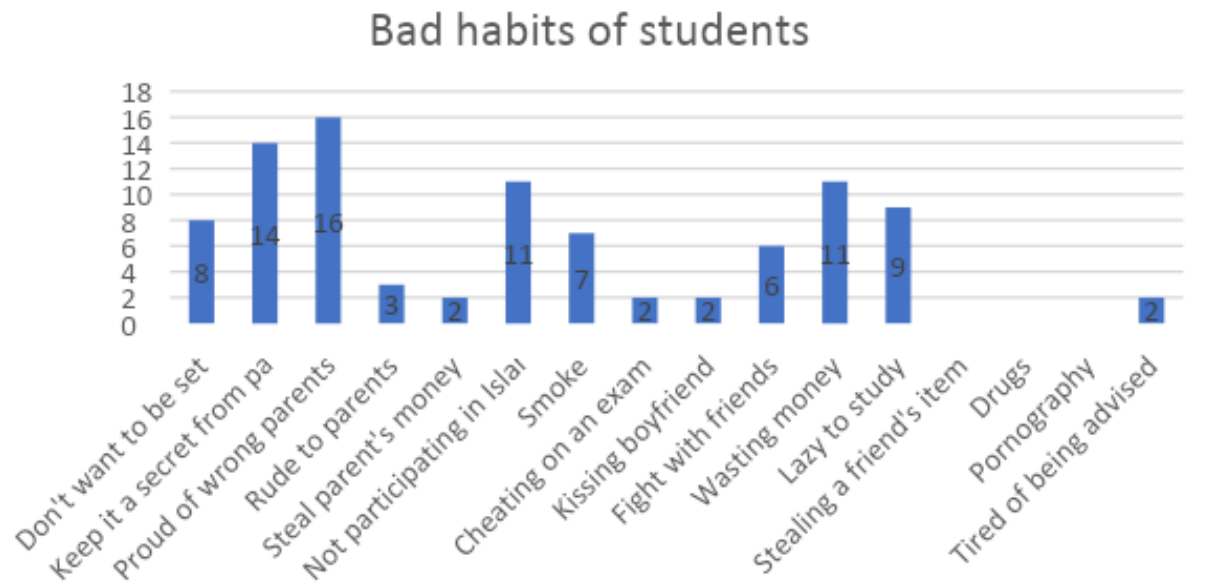

Figure 1: Student Bad Habits

Based on the data above, it can be seen that of the 16 kinds of bad habits that are mostly done by 399 students are first, feel proud that their parents apologize. It means the child feels right, and their parents are wrong. Second, the habits of children to keep their traveling as a secret from their parents. It shows that children have a habit of lying and being close to their parents, but open to their peers. As for the third place, children are lazy to take the recitation in the village, children prefer to spend fun with their gang friends, fight, lazy to learn, and refuse to be disciplined

The bad habits that are sometimes carried out by Muhammadiyah Middle School students are yelling at parents, stealing parents' money, cheating on exams, kissing their girlfriends, feeling bored when advised by both teachers and parents. While bad behavior that has never been done by the students is stealing friends' money, using drugs, and viewing pornography.

Based on the explanation above, the bad habits of students can be classified into three types, namely: a. The aspects of student personality that still need guidance, such as how to respect parents, a closed attitude with parents, feel that they do not need rules of life. b. Aspects of social relations that still need to be fostered about the importance of honesty (Suud, 2019) that brings blessing, and the limits of association with non-muhrim. c. The aspect of controlling appetite is relatively good enough because they do not commit crime, drugs, and pornography.

Thus overall, the bad behavior of Muhammadiyah Middle School students can be illustrated in Figure 2.

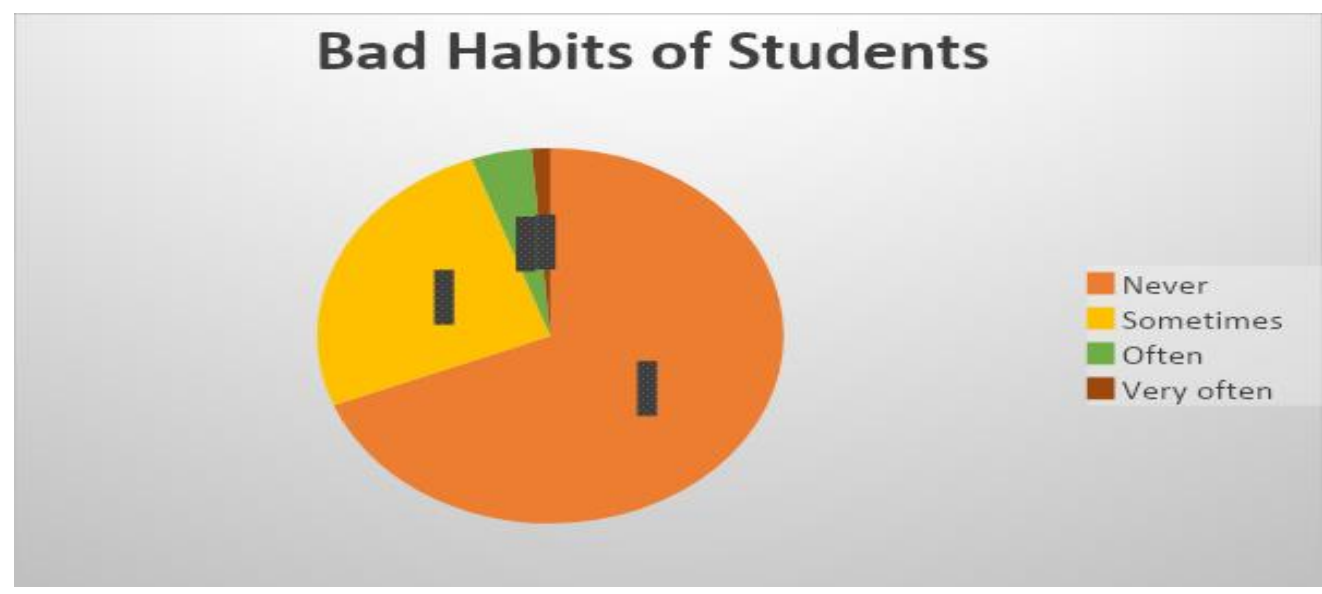

Figure 2: Percentage of Student Bad Habits

In the pie chart, it can be seen that the bad habits that are sometimes done by students compared to the bad habits that have never been done, greater the bad habits that are sometimes carried out at $69 \%$. This shows that the bad habits of Muhammadiyah Middle School students are still relatively high. Because it is still done by most students, it means that almost some students still consider that student delinquency is normal.

Thus, the form of the negative behavior of Muhammadiyah Middle School students in schools is still in the category of low delinquency such as smoking, doodles, tardiness, skipping school, bullying friends, and joining gangs. Whereas negative behavior in the family that is done by students, mostly attitudes against parents, but open with peers. They 
spend more time playing a cellphone than studying and worship. Likewise, concerning the habit of using Muslim clothing, it is still understood as a school uniform and not as Islamic law for women who are baligh.

\section{Character Education Program at Muhammadiyah Middle School}

\section{Prioritized Character Education Values}

Based on the results of interviews with two principals of Muhammadiyah Junior High Schools, Prambanan, and Pakem, the data obtained was

"The character values instilled in this school are adjusted to our school's mission of prioritizing karimah to be the main point in school activities in improving behavior always to do good. The value of character education that is always instilled in students is the value of courtesy, discipline, honesty, the habit of prayer, hard work, cleanliness, friendliness with fellow friends ".

The opinions of the two Muhammadiyah Middle School principals represent the opinion of the other school principals stating that akhlakulkarimahis the main objective of educating students in Muhammadiyah schools. As indicated by the headmaster of the Muhammadiyah 1 Depok Junior High School,

"Character education that is carried out in this school is not only limited as a motivation but as a habit. It was also strengthened by affirmations from mahfuzhot (Arabic aphorisms), and the study of certain verses in the al-Quran, such as QS. al-Mulk and al-Lukman. All of these activities are details of the school's vision religious and having high achievement. Character education is derived from the religious vision, Nineteen character values from the Ministry of Education and Culture, reconstructed into five and accustomed to $5 S$ (senyum, salam, sapa, sopan,santun). There is also the custom of Dhuhr and Asr prayer in congregation, coupled with a study of the values of Islam every Friday ".

Based on the explanation of the headmaster, it can be seen that the character education program taught at Muhammadiyah Middle School is not only theoretical but also practical. The establishment of morality in the Muhammadiyah school focused more on the religious attitude of students. Such as habituation for prayer in congregation, attending Islamic studies. The value of character education that is always instilled in students at SMP Muhammadiyah Sleman refers to the importance of courtesy, discipline, honesty, the habit of prayer, hard work, cleanliness, friendliness with fellow friends. Strengthening characters such as honesty (Suud, 2019) is very important to embed it through cognitive and also habituation and role models.

Whereas the value of character education trained in the Muhammadiyah Bantul Middle School, mostly in the form of internalization of character values by getting used to the prayer, honesty, discipline, responsibility, independence, and spirituality. To instill the value of the child's independence character, it is done by leaving the child in the community four days three nights with the aim of training independence (such as scouts). It is also trained so that children dare to speak in public with a rotating preaching program after prayer. All the values of character education start from the teacher's example, then become a rule that must be followed by all students. Muhammadiyah school teachers have also been joined in training to strengthen character education held by PP Muhammadiyah with the Directorate of Basic Education of the Ministry of Education and Culture for seven days and trained to make reinforcement, especially character building. The results of the training are then drafted and then communicated to the staff of the teachers and also to the parents so that all are involved in the character-building plan.

\section{Principal's program in Character Education}

The various headmaster programs related to character education by three Muhammadiyah Middle School principals in Sleman are as follows:

"The school principal facilitates children's talents with various extracurricular programs. Besides that, they also make rules or procedures for the handling of children with problems by giving points to the level of student delinquency and the form of punishment. Example: when there are students who have problems, they will be called to the counseling team or homeroom teacher and then given education, counseling, and so forth. But if it is already difficult to give them advice, then given a Warning Letter 1,2 , and if it can not also change, then the students will be returned to parents. Furthermore, the principal also analyzes the problems experienced by those children and looks for causes and solutions so that the other children do not deviate. Furthermore, a school program was made in the form of activities that were supervised by the vice principal in student affairs and in collaboration with external parties such as the police, sub-village who were ready to supervise students outside the school and also held parenting training for parents."

Programs created by principals to strengthen character education are through various means, including (1) facilitating children's talents by providing multiple extracurricular programs. (2) Making the rules or procedures for handling children with problems by giving points to the level of student delinquency and the form of punishment, (3) Analyzing issues experienced by children and looking for causes and solutions by establishing cooperation with external parties. 
How to overcome the delinquency of students in Banguntapan, Imogiri and Featured Aisyiyah Bantul is done by: (1) making the stages of student counseling begin from calling students to the homeroom teacher than to the counseling team by giving the student the responsibility to remind his friends not to be like him. (2) provide penalties such as carrying flowers, and when it becomes severe, they will be suspended. The goal is to make students a deterrent. (3) holding a home visit program that aims to find out the cause of children who skip school. (4) searching when students enter school or after the ceremony.

\section{Instructional Leadership Ability of the Principal of Muhammadiyah Middle School}

Poor Principal's Ability.

Based on the results of the assessment of 135 teachers regarding the ability of the Muhammadiyah Middle School Principal, it can be seen that the expertise that is most judged to be inadequate is the ability of the principal to become a model person in his learning abilities. Besides, the ability of school principals to make achievement targets as well as the lack of enthusiasm to advance the school as can be seen in Figure 3.

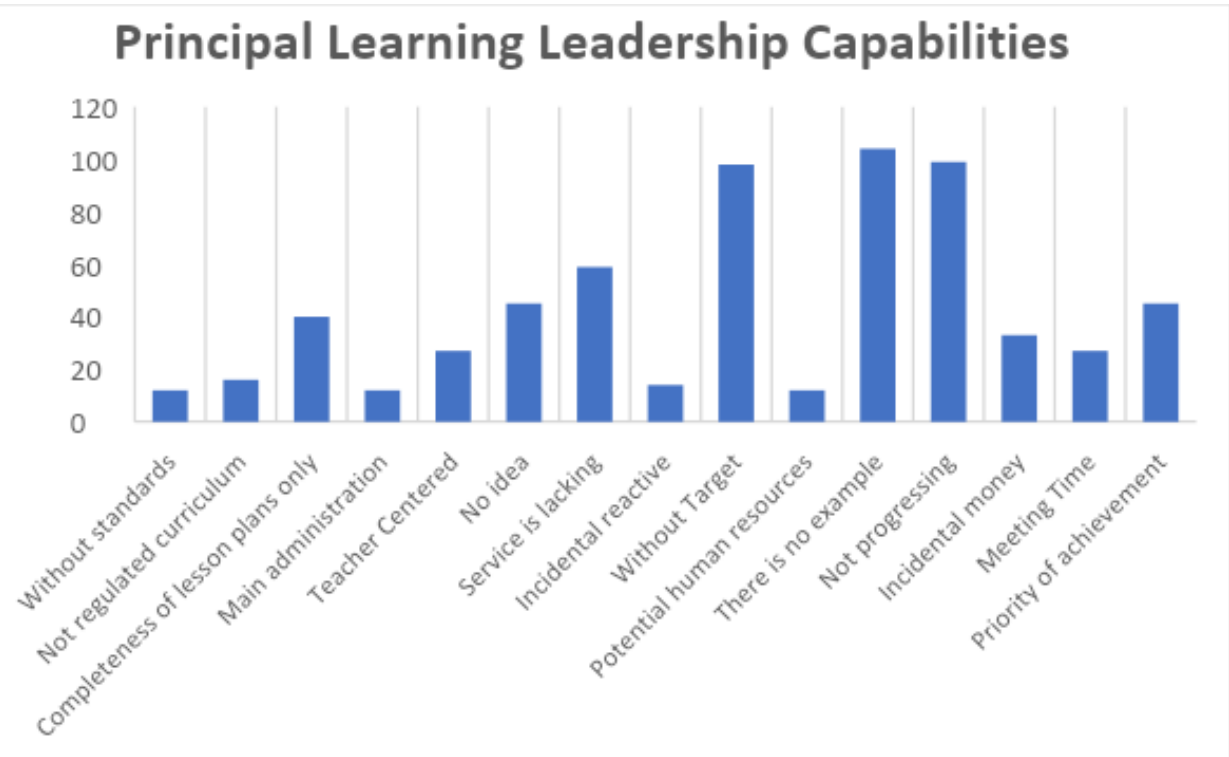

Figure 3: Principal's Capabilities

Based on the histogram image, the ability of principals that are still low at the second level is first, the ability to provide services to students and teachers that are still unsatisfactory. Second, principals prioritize more on student academic achievement, the completeness of the teacher's lesson plan without looking directly at the teacher's ability to teach. Third, the ability of principals to run leadership learning has not yet been seen to improve student character. The lowest ability of school principals at the third level is the ability to conduct monev of learning, which is not incidental, does not have the idea of school character development, the principal does not direct learning. Still, it is left to each teacher, so the direction is not clear. The use of time for meetings is still high in morning hours, which is best for learning. The learning model is still teacher-centered, and there are no standard implementation procedures.

Thus it can be concluded that the ability of Muhammadiyah Junior High School principals in the teacher's assessment is not good, because there are still many abilities that have not been realized, such as the ability to set school achievement targets, strategies to achieve school goals, as well as the ability to create learning service standards for character building.

\section{Good Principal's Ability}

The ability of principals, which are categorized as well such as in realizing cohesiveness between teachers and students, improving the quality of human resources, being visionary, and directing them to progress. It is the principal capital to advance the school. As can be seen in Figure 4.

In the histogram above, it can be seen that the ability of the principal to be classified as a medium is the ability to cultivate monitoring and evaluation, be centered on students, implement the lesson plans, and have operational learning standards while the ability that is still relatively low is the ability to assess performance, the ability to measure the effectiveness of achieving school goals, and the ability to prioritize service in leadership. These three abilities are still relatively low, so improvement efforts are needed through the training of principals in evaluating performance, as well as training to measure the achievement of school goals. It also needs to be given leadership training in service-oriented principals. 


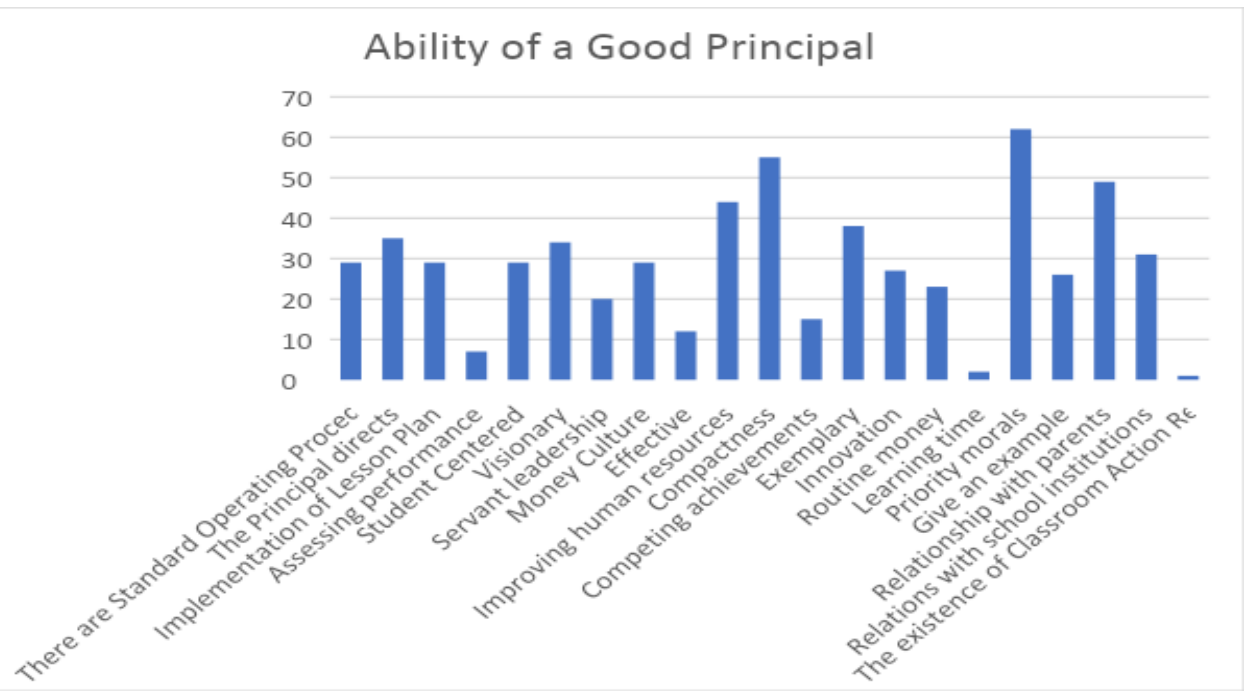

Figure 4: Good Principal Skills

\section{The Success of Developing Character Education in Muhammadiyah Middle School}

The success of character education development in Muhammadiyah Middle School as stated by several school principals in Bantul Regency:

"Now the children have started to improve, there used to be some children who are lazy to pray at dzhur, now alhamdulillah they do it, there are children who were shy now that they have started to be active, even some children who are dishonest after the honesty canteen program can be honest. The discipline attitude when the student goes to school is getting better. The teacher has to do home visits to some children who are naughty and skipping school. The school also helps the students to get used to pray and read the al Quran"

The principal's statement shows that the students' character changes are to be diligent in worship, to be brave in front of the public, to be honest, more disciplined, through the habituation method. To overcome the child's delinquency, counseling is also done by all homeroom teachers, if still not successful, then submitted to the Counselling teacher. Even though most of the children can still be directed and some of them are difficult to be reminded but in general the level of success is running. "

To find out more about the success rate of character education in Muhammadiyah Middle School, it can be seen through the following questionnaire results.

\section{Good habits}

According to the avowal of Muhammadiyah Middle School students from the questionnaire, they filled in, data can be obtained that the six good habits such as rushing prayers when listening to the adzan, routine tadarus, reciting wiri and prayers after sholat, not bothering parents, hanging out with friends who are smart and pious, and make parents happy, can be seen in the following diagram.

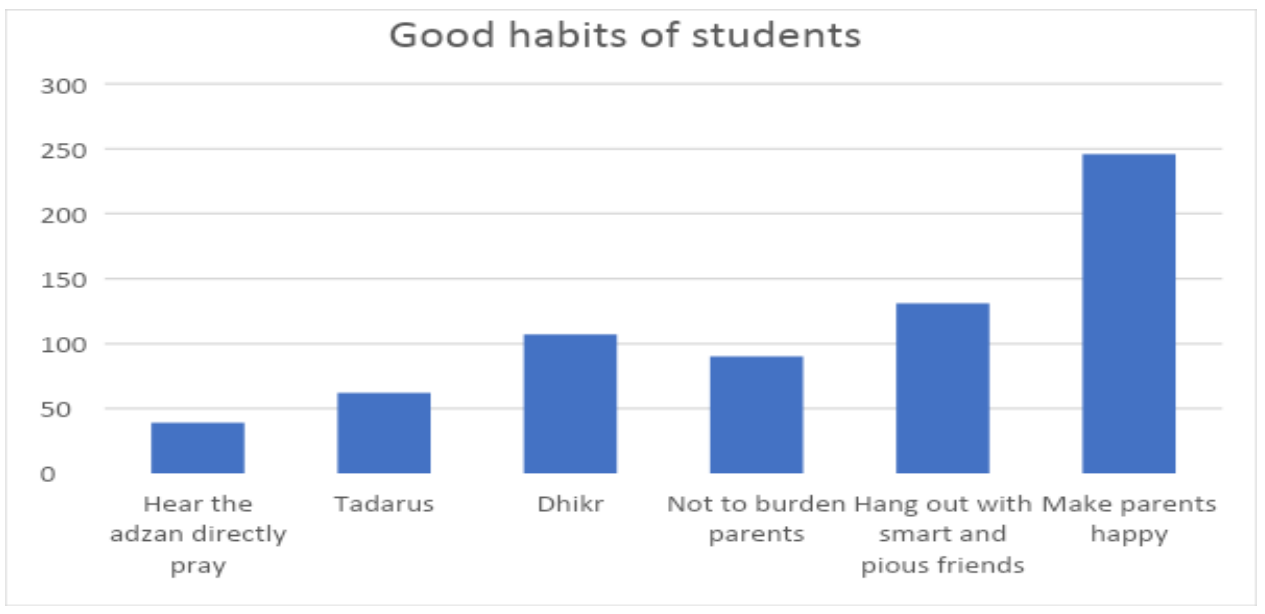

Figure 5: Good Habits of Students 
In the diagram drawings, it can be seen that the highest good habits practiced by students are the desire to excel in making parents happy. These good habits are the principal capital for building student character. Because God's blessing depends on the blessing of their parents. Furthermore, the second level of good habits is the habit of reciting prayer and dhikr after every prayer. This practice is carried out by less than half of the students. Yet this habit, if routinely carried out, will have an impact on peace of mind and the fulfillment of prayer because it is at an obligatory time. The second right level of habit is to enjoy hanging out with smart, pious friends. The habit of choosing good friends is an outstanding influence because it can learn and imitate the excellent habits of friends who are intelligent and pious.

While good habits that at last place is to rush prayer when hearing the adzan anywhere, and tadarus al-Qur'an every day even though only five verses, then followed by the habit of trying not to bother parents. Based on the data above, it can be illustrated that overall the good habits of Muhammadiyah Middle School students consisting of the habit of hastening prayer when hearing the call to prayer, the habit of daily prayers, and the habit of $d h i k r$ after prayer is still relatively low because $44 \%$ of students fill the often column while those who have been classified as practicing the habit are only $5 \%$ of students.

\section{Good behavior}

The six good behaviors that have been carried out by Muhammadiyah Middle School students as positive characters: being patient about friends' teasing, focusing on being a class champion, like reading and summarizing textbooks, wanting to continue into universities, spending free time to attend tutoring, and being tolerant for differences of opinion. The ability of students to behave appropriately can be seen in the following diagram.

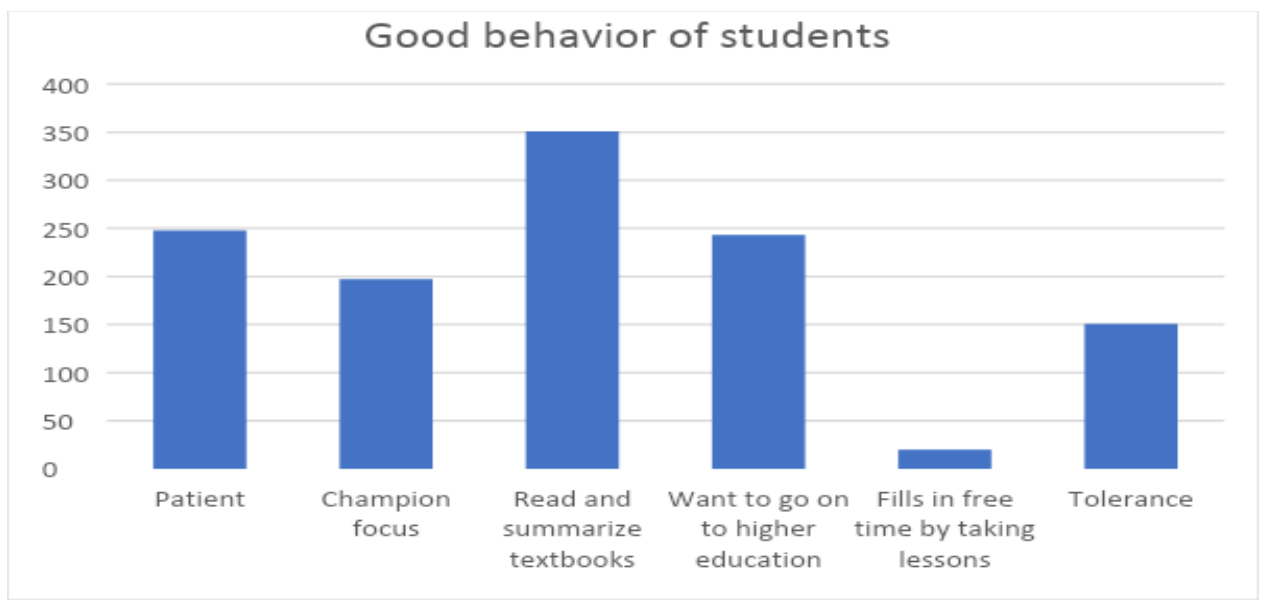

Figure 6: Good Behavior of Students

Based on the data in the histogram above, it can be seen that the ethical behavior of students who have stood out well is the behavior in reading and summarizing the lesson. It shows the students have high achievement motivation. The second level is patient behavior with ridicule of others, and the high desire of students to go to universities, and keep their focus to become class champion. It is good to foster students into people who have excelled. While the behavior that is still classified as very low is to fill spare time by taking lessons outside the class. It is because the respondents surveyed were not from the $3^{\text {rd }}$ grade, so they felt they did not need to take additional lessons.

Overall good behavior of Muhammadiyah Middle School students in Yogyakarta is often carried out as much as $37 \%$, not to the level of frequent or very frequent, as in Figure 7.

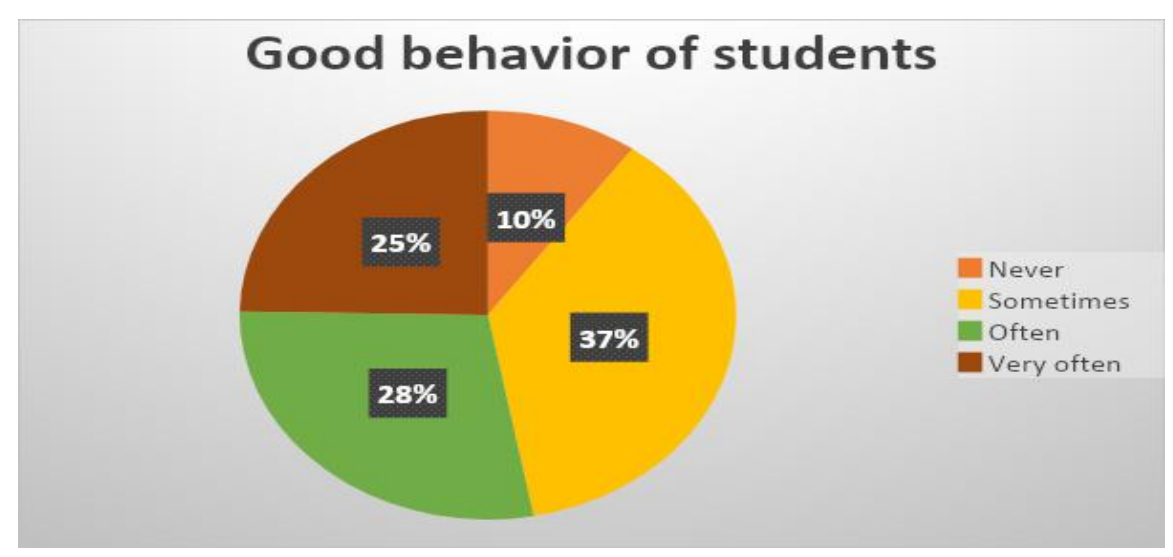

Figure 7: Percentage of Student Good Behavior 
In the pie chart above, it can be seen that the majority of Muhammadiyah Middle School students perform good behavior frequently and often. And there are only $10 \%$ of students who have never done such good behavior. It shows that not all students behave well regularly, which has become a character. There are still $37 \%$ of students who often appear to behave well. In fact, there are still only a few students who have not done good behavior.

\title{
Effect of Principal's Leadership Ability on Student Character
}

The influence of principal leadership learning abilities on changes in student character can be seen in the results of the regression analysis as follows.

Table 1: Regression Analysis

\begin{tabular}{|c|c|c|c|c|c|c|c|c|c|}
\hline \multirow[b]{2}{*}{ Model } & \multirow[b]{2}{*}{$\mathrm{R}$} & \multirow[b]{2}{*}{$\begin{array}{c}\mathrm{R} \\
\text { Square }\end{array}$} & \multirow{2}{*}{$\begin{array}{l}\text { Adjusted R } \\
\text { Square }\end{array}$} & \multirow{2}{*}{$\begin{array}{l}\text { Std. An } \\
\text { error of the } \\
\text { Estimate }\end{array}$} & \multicolumn{5}{|c|}{ Change Statistics } \\
\hline & & & & & $\begin{array}{l}\text { R Square } \\
\text { Change }\end{array}$ & F Change & df1 & df 2 & Sig. F Change \\
\hline 1 & $\begin{array}{c}347 \\
a\end{array}$ & .120 & .052 & 9.270 & .120 & 1.775 & 1 & 13 & .206 \\
\hline \multicolumn{10}{|c|}{ a. Predictors: (Constant), Leadership } \\
\hline \multicolumn{10}{|c|}{ b. Dependent Variable: Character } \\
\hline
\end{tabular}

Based on the results of calculations using the linear regression formula, we obtained the results that there is an influence between the leadership ability of the principal and the level of student character. The magnitude of the impact of principal leadership learning abilities on changes in student character is only $12 \%$, and other factors influence $78 \%$. The other factors could be the influence of parenting, and the environment of the community, where the student resides.

\section{Inhibiting factors for Principal Instructional Leadership Ability}

The inhibiting factors of the principal's learning leadership are as stated by the principal in Banguntapan, Imogiri, and Bantul as follows.

\begin{abstract}
"Internal factors are usually many teachers who are already old so that they are not optimal in conducting the teaching and learning process. External factors are generally from the family or parents of students who allow or do not get used to the culture that has been applied at school. Perhaps one of the external factors is that parents do not support programs to overcome juvenile delinquency in schools. The internal factor is more on the role of the teacher to be a good example, and there are some teachers (minorities) who give bad examples, such as when the prayer in congregation ends or masbuq."
\end{abstract}

Likewise, the principals of Prambanan, Depok, and PakemSleman stated as follows:

"Lack of school cooperation with parents. The awareness of parents is so low that even they left all of the responsibilities of the child to the teachers, the parents do not monitor their child outside the school. It has an impact on the development of children in schools in terms of discipline, politeness, and perseverance in learning that is still lacking. Sometimes problems start from the disharmony of households brought to school, children often causing trouble at school ".

Based on the two narratives, it can be seen that the obstacles most felt by principals in carrying out learning leadership are: First, the lack of facilities for worship and means of supporting learning media. It is because places of worship cannot accommodate all students, so character building through worship activities cannot be comprehensive. The absence of LCD, resulting in an explanation of the lesson can not be shown clearly in the video. Second, the lack of teachers as role models in the discipline aspect, communication that is not polite, as well as the existence of old fashion teachers. It is in line with research (Paula, 2019) that good communication between students and parents has a significant influence on the quality of life. Third, parents who do not get used to the positive culture that has been implemented in schools. Like a child allowed to ride a motorcycle even though the school prohibits because they do not have a SIM. Research (Carmen 2018), also shows that the principal's leadership, especially in terms of shaping the character of good students, must involve support from the state. Fourth, lack of school collaboration with parents of students in educating children with one vision. It is in line with research (Irene Korstjens, 2020), that good communication between parents and schools has a significant influence.

\section{CONCLUSION}

The form of the negative behavior of Muhammadiyah Junior High School students in schools is still in the category of low delinquency such as smoking, scribbling, tardiness, skipping school, bullying friends, and joining gangs. Whereas negative behavior in the family that is done by students is against parents but open with peers. More time is spent on students playing cellphone than studying and worshiping. All of the mischief sources is because they are lazy to worship. Programs created by school principals to strengthen character education are (1) facilitating children's talents by providing various extracurricular programs. (2) Making rules or procedures for handling children with problems by giving level 
points of student delinquency and the form of punishment, (3) Analyzing issues experienced by children and looking for causes and solutions by establishing cooperation with external parties.

The instructional leadership ability of the Muhammadiyah Middle School principals, according to teacher ratings, is still low. Especially the ability to formulate school achievement targets, strategies for achieving school goals, the ability to create learning service standards to shape character, and the ability to develop patterns for fostering teacher competency development. The success to promoting the Islamic moral character of Muhammadiyah Middle School students can be known through changes in the character of students, such as being diligent in worship by getting dzikir after prayer, being brave, being honest, being more disciplined, having the desire to please parents, and getting used to reading and summarizing books. The magnitude of the influence of school leadership learning leadership abilities with changes in student character is only $12 \%$, and other factors influence $78 \%$.

The inhibiting factor of instructional leadership of Muhammadiyah Middle School principals in the formation of student character is due to the lack of cooperation to unite the vision between the school and parents in educating children. So what is taught in school is not supported by parenting in the family. Besides, the exemplary factor of some teachers regarding Islamic character is still minimal.

\section{LIMITATION AND STUDY FORWARD}

This research was conducted at Muhammadiyah schools, which are loaded with religious and Muhammadiyah education. Of course, the results of the study will be different from other schools that are not Muhammadiyah schools. So we suggest that other researchers can do the same research in various schools to see how the results are found.

\section{ACKNOWLEDGMENT}

Thank you to all informants and participants in this study, so that the necessary data can be found properly. Thank the Co-Author, who helped with the completion of this article.

\section{AUTHORS CONTRIBUTION}

The main author has the primary responsibility of completing the research by preparing all material and compiling the research procedures. The second author is tasked with organizing the results of the investigation into articles for later submitting to journals that match the scope. The third author is responsible for preparing the manuscript to submit in the appropriate journal including following the author's guidelines.

\section{REFERENCES}

1. Arifin, I. (2017). Kepemimpinan pembelajaran kepala sekolah dalam menerapkan pendidikan karakter pada era masyarakat ekonomi asean.

2. Bafadal, I. (2016). Peningkatan Mutu Pendidikan Melalui Kepemimpinan Pembelajaran. Materi Talk Show.

3. Baidarus, B., Hamami, T., Suud, F. M., \& Rahmatullah, A. S. (2020). Al-Islam dankemuhammadiyahansebagai basis pendidikan karakter. AL-ASASIYYA: Journal Of Basic Education, 4(1), 71-91. https://doi.org/10.24269/ajbe.v4i1.2101

4. Carmen Montecinos, Tony Bush, FelipeAravena (2018). Moving the school forward: Problems reported by novice and experienced principals during a succession process in Chile. International Journal of Educational Development, Volume 62, (2018). Pages 201-208, ISSN 0738-0593.

5. Chris Brown, Jane Flood (2020). The three roles of school leaders in maximizing the impact of Professional Learning Networks: A case study from England. International Journal of Educational Research, Volume 99, 101516, ISSN 0883-0355. https://doi.org/10.1016/j.ijedudev.2018.04.004

6. Daniëls, E., Hondeghem, A., \&Dochy, F. (2019). A review of leadership and leadership development in educational settings. Educational Research Review. https://doi.org/10.1016/j.edurev.2019.02.003

7. Davis, G.A., \& Thomas, M.A. (1989). Effective Schools and Effective Teachers. Boston: Allyn and Bacon.

8. De Roche, E.F. (1987). An Administrator's Guide for Evaluating Programs and Personnel: An Effective Schools Approach. Boston: Allyn and Bacon, Inc.

9. Gorton, R.A., \& Schneider, G.T. (1991). Schools-Based Leadership: Challenges and Opportunities. Dubuque, Iowa: WimC.Brown Company Publisher.

10. Greenfield, W.D. (1987). Instructional Leadership: Concepts, Issue, and Controversies. Boston: Allyn and Bacon.

11. Hallinger, P., \&Leithwood, K. (1994). Introduction: Exploring the Impact on Principal Leadership. School Effectiveness and School Improvement: An International Journal of Research, Policy, and Practice. September, 5(3): 206-218. https://doi.org/10.1080/0924345940050301

12. Heck, R.H.; Larsen, T.J.,\& Marcoulides, G.A. (1990). Instructional Leadership and School Achievement: Validation of a Causal Model. Educational Administration Quarterly, 26(2): 94-125. https://doi.org/10.1016/j.ijer.2019.101516

13. B.Mitchel\&L.L.Cuningham(Eds). Educational Leadership and changing Contacts of families, Comonites, and Schools. Chicago: University of Chicago Press. 
14. Irene Korstjens, Jessica Mesman, Isabel van Helmond, Raymond de Vries, Marianne Nieuwenhuijze (2020). The paradoxes of communication and collaboration in maternity care: A video-reflexivity study with professionals and parents, Women and Birth. https://doi.org/10.1016/j.wombi.2020.01.014

15. Jean-Baptiste M.B. Sanfo (2020). A three-level hierarchical linear model analysis of the effect of school principals' factors on primary school students' learning achievements in Burkina Faso, International Journal of Educational Research, Volume 100. 101531. https://doi.org/10.1016/j.ijer.2020.101531

16. Kemendiknas. (2007). Permendiknas No. 13 Tahun 2007 tentangStandarKepalaSekolah/Madrasah. Jakarta: Diknas.

17. Khilmiyah. Akif (2017). Evaluasi Kompetensi Kepemimpinan Kepala Sekolah Muhammadiyah. Yogyakarta: LP3M UMY

18. Kleine-Kracht, S.P. (1993). Indirect Instructional Leadership: An Administrator's Choice. Educational Administration Quarterly, 29(2): 187-212. https://doi.org/10.1177/0013161X93029002005

19. Kusmintardjo. (2003). Kepemimpinan Pembelajaran Kepala Sekolah dalam Meningkatkan Kinerja Guru. DisertasiTidakDiterbitkan. Malang: PPS UM.

20. Lickona, T. (2004). Character Matters. New York: Touchstone Rockefeller Center.Malang: UIN Maliki Press.

21. Mulyadi. (2010). KepemimpinanKepalaSekolahdalamMengembangkanBudayaMutu.

22. Murfpy. J (1990). Preparing school Administrators for the twenty-first century: The reform agenda Noelle A. Paufler, Edward F. Sloat, Using standards to evaluate accountability policy in context: School administrator and teacher perceptions of a teacher evaluation system, Studies in Educational Evaluation, Volume 64, (2020), 100806, ISSN 0191-491X, https://doi.org/10.1016/j.stueduc.2019.07.007

23. Orven E. Llantos, Maria Regina Justina E. Estuar(2019). Characterizing Instructional Leader Interactions in a Social Learning Management System using Social Network Analysis, Procedia Computer Science, Volume 160, , Pages 149-156, ISSN 1877-0509. https://doi.org/10.1016/j.procs.2019.09.455

24. Paula San-Martín, Ana Fernández-Laviada, Andrea Pérez, EstefaníaPalazuelos(2019). The teacher of entrepreneurship as a role model: Students' and teachers' perceptions, The International Journal of Management Education, , 100358, ISSN 1472-8117, https://doi.org/10.1016/j.ijme.2019.100358

25. Rossow. L.F. (1990). The Principalship: Dimensions in Instructional Leadership. Boston: Allyn and Bacon.

26. Smith W.F., \& Andrews, R.L. (1989). Instructional Leadership: How Principals Make A Difference. Washington, DC: ASCD Publications.

27. Suud, F. M., \&Madjid, A. (2019). The Study Of Educational Honesty Stages Implementation In An Indonesian School. Humanities \& Social Sciences Reviews, 7(4), 502-510. https://doi.org/10.18510/hssr.2019.7467

28. Suud, F. M. (2018). KepemimpinanTransformasionaldanImplikasinyapadaPembentukanBudayaJujur di Sekolah. Sukma: JurnalPendidikan, 2(2), 261-286. https://doi.org/10.32533/02206.2018

29. Ubben, G.C., \& Hughes, L.W. (1992). The Principal: Creative Leadership for Effective Schools. Boston: Allyn and Bacon. 